\title{
The diversity, status and conservation of small carnivores in a montane tropical forest in northern Laos
}

\author{
ARlyne JOHNSON, CHANTHAVY VONGKHAMHENG and ThaVis OUK SAITHONgDAM
}

\begin{abstract}
Laos harbours globally significant populations of small carnivores, including mustelids and viverrids of conservation concern and felids that are relatively rare or unknown from other parts of Asia. However, few have received conservation attention as managers still lack basic information on the status and distribution of even the most common species. We conducted the country's first systematic camera-trap monitoring of carnivores in the Nam EtPhou Louey National Protected Area on the Laos-Vietnam border, with intensive sampling across $500 \mathrm{~km}^{2}$ from 543 to 2,288 m altitude for 8,499 camera-trap days during 20032006. Surveys detected 14 species of small carnivores, including the first record of Owston's civet Chrotogale owstoni for Laos. Preliminary occupancy estimates for the seven most common species ranged from $11 \%$ for marbled cat Pardofelis marmorata to $42 \%$ for Asian golden cat Pardofelis temminckii. Activity patterns of viverrids were primarily nocturnal whereas mustelids, except for hog badger Arctonyx collaris, were diurnal. Leopard cat Prionailurus bengalensis was largely nocturnal, marbled cat primarily diurnal and Asian golden cat as likely detected during the day as at night. Our results led to the establishment of a contiguous $3,000-\mathrm{km}^{2}$ protected area core zone and regulations that protect threatened species and control harvest of managed species.
\end{abstract}

Keywords Camera trapping, felids, Laos, mustelids, Nam Et-Phou Louey National Protected Area, viverrids, wildlife monitoring

\section{Introduction}

T aos lies within the second most important area for 1 small carnivore taxa (mustelids and viverrids) of conservation concern (Schreiber et al., 1989). The country also harbours potentially important populations of Asian golden cat Pardofelis temminckii and marbled cat Pardofelis marmorata that are of conservation concern and relatively rare in other areas of Asia (Duckworth et al., 1999; Sunquist \& Sunquist, 2002; IUCN, 2008).

Arlyne Johnson (Corresponding author), Chanthavy Vongkhamheng and Thavisouk Saithongdam Wildlife Conservation Society-Lao PDR Program, Box 6712, Vientiane, Lao PDR. E-mail ajohnson@wcs.org

Received 1 June 2008. Revision requested 24 July 2008.

Accepted 17 September 2008.
Despite their importance small carnivores have received little conservation attention and remain among the least known groups of higher vertebrates in Laos (Duckworth, 1997). New records came from surveys in the 1990 (Duckworth et al., 1999) but no long-term studies have been undertaken. Duckworth's (1997) review predicted that studies north of $18^{\circ} 40^{\prime} \mathrm{N}$ at sites above 1,200 $\mathrm{m}$ would yield valuable new information. The study reported here, north of $19^{\circ} \mathrm{N}$ and in locations up to $2,288 \mathrm{~m}$, represents the longest systematic camera trapping effort to assess status and distribution of carnivores over consecutive years at any location in Laos.

Hunting and habitat loss are cited as major threats to small carnivores in Laos (Duckworth, 1997) but little is known about the impact of these threats. Although Laos has $>40 \%$ forest cover and only 22 people $\mathrm{km}^{-2}$ (ICEM, 2003) subsistence hunting is widespread, with guns, dogs and snares used to harvest small carnivores for food and medicine (Johnson et al., 2005). Since 1987, when Laos adopted a free market economy, hunting has evolved to meet domestic and international demand for wildlife products, with illegal trade the second biggest source of cash for rural families in some areas (Nooren \& Claridge, 2001). Small carnivores are sold for food, body parts (bones, glands and organs), medicine or perfume, and pelts for furs. Simultaneously, habitat loss driven by shifting cultivation, logging and conversion of natural forests to plantations is proceeding at an unprecedented rate (GoL, 2005).

A new national wildlife law, ratified by the National Assembly on 24 December 2007 mandates full protection for most felids and rarer viverrids and mustelids, although other small carnivores can be hunted for subsistence consumption outside protected area core zones during specified seasons and at a sustainable rate (GoL, 2007). However, wildlife managers still lack basic information on the status and distribution of even the most common small carnivores. Without this it is impossible to know if protected populations are being maintained or if harvests of hunted species are sustainable. This study in the Nam Et-Phou Louey National Protected Area provides baseline data for managers on the occurrence and distribution of 14 small carnivore species, and new findings relative to what is known from elsewhere across their range.

\section{Methods}

The $5,950-\mathrm{km}^{2}$ Nam Et-Phou Louey National Protected Area is the largest protected area in Laos (Fig. 1). Altitudes 


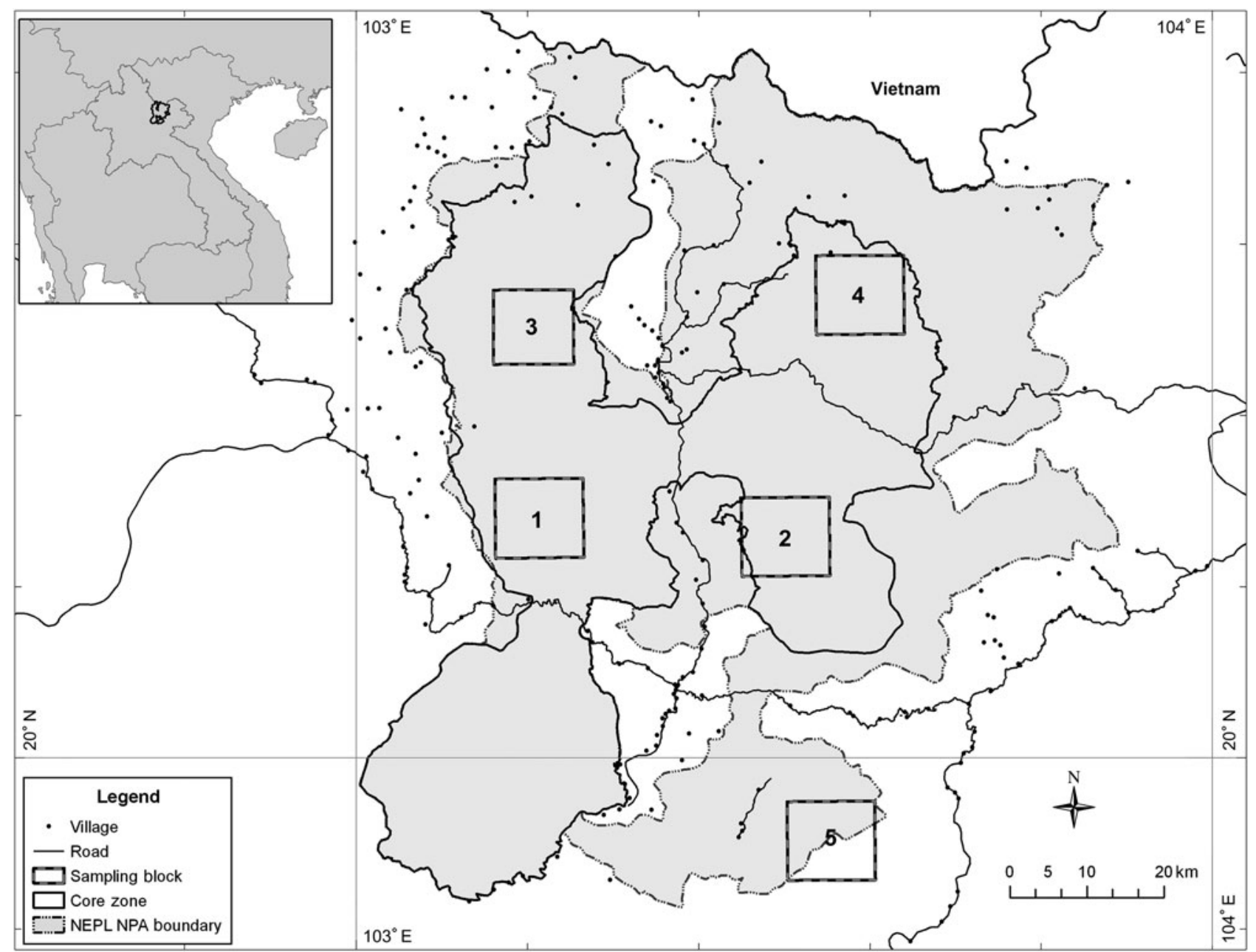

FIG. 1 The Nam Et-Phou Louey National Protected Area (NEPL NPA), Laos, showing the five numbered sampling blocks surveyed during 2003-2006 (Table 1). The coordinates of the south-west corner of the sampling blocks are: (1) $103^{\circ} 9^{\prime} 44^{\prime \prime} \mathrm{E}, 20^{\circ} 13^{\prime} 48^{\prime \prime} \mathrm{N}$; $(2)$ $103^{\circ} 26^{\prime} 57^{\prime \prime}$ E, $20^{\circ} 13^{\prime} 25^{\prime \prime} \mathrm{N}$; (3) $103^{\circ} 9^{\prime} 34^{\prime \prime} \mathrm{E}, 20^{\circ} 27^{\prime} 21^{\prime \prime} \mathrm{N}$; (4) $103^{\circ} 31^{\prime} 58^{\prime \prime} \mathrm{E}, 20^{\circ} 29^{\prime} 44^{\prime \prime} \mathrm{N}$ and (5) $103^{\circ} 30^{\prime} 2^{\prime \prime} \mathrm{E}, 1^{\circ} 51^{\prime} 46^{\prime \prime} \mathrm{N}$. The inset shows the location of the Protected Area in Laos.

range from 400 to $2,288 \mathrm{~m}$, with $>60 \%$ of land area above $1,000 \mathrm{~m}$ and $91 \%$ on slopes greater than $12 \%$. Annual rainfall is $1,400-1,800 \mathrm{~mm}$ (May to October) and temperatures range from $5^{\circ} \mathrm{C}$ (December-February) to $30^{\circ} \mathrm{C}$ (April-July). The landscape is dominated by mixed evergreen-deciduous forest up to $1,500 \mathrm{~m}$, transitioning into evergreen forest at 1,500-1,800 $\mathrm{m}$, and interspersed with beech and rhododendron species above 1,800 m (Davidson, 1998).

Data on small carnivores were collected while carrying out camera-trap surveys to assess tiger and prey populations (Johnson et al., 2006) from March 2003 to April 2006 (Table 1). Fifty CamTrakker (CamTrakker, Watkinsville, USA) passive infrared camera traps were set in each of five $100 \mathrm{~km}^{2}$ sampling blocks in the National Protected Area, as far away from villages as possible $(2.2-13.6 \mathrm{~km}$; Fig. 1$)$. The 50 traps were rotated between blocks for a total of 11 sampling periods (Table 1). Each block was divided into $254 \mathrm{~km}^{2}$ subunits with one camera pair per sub-unit. Camera pairs were placed near active animal trails within $500 \mathrm{~m}$ of a random coordinate, and a global positioning system was used to record location and altitude. Trap sites were from 543 to 2,288 m altitude. Most sites ( $77 \%$; 6,471 camera-trap days) were below $1,500 \mathrm{~m}$ in mixed evergreen-deciduous forest, followed by $20 \%$ (1,790 camera-trap days) from 1,500 to $1,800 \mathrm{~m}$ and $3 \%$ (238 camera-trap days) above $1,800 \mathrm{~m}$.

Forest structure within a $10-\mathrm{m}$ radius of each trap site was classified following a standardized typology (Webb et al., 1976). Cameras were mounted on trees at $45 \mathrm{~cm}$ above the ground and operated 24 hours per day with a 20 -second delay between sequential photographs, and left in the forest for a minimum of 37 days. Trap days per camera were calculated from the time the camera was mounted until the date of the final photo or retrieval of the camera. Cameratrap days per site was calculated from only one camera of each camera pair; if camera-trap days varied within the pair, the larger number was used.

Data from the first survey in each of the five blocks (March 2003-May 2004; Table 1) were analysed using 
TABle 1 Camera trap sampling dates, effort and altitude in five blocks in Nam Et-Phou Louey National Protected Area, Laos (Fig. 1), during 2003-2006.

\begin{tabular}{|c|c|c|c|c|c|}
\hline Block, site name & Date & Duration (days) & Camera points (cameras) & Trap days & Altitude (m) \\
\hline \multirow[t]{3}{*}{ 1, Phou Louey } & Mar.-Apr. 2003 & 55 & $25(49)$ & 828 & $1,137-2,288$ \\
\hline & Oct.-Dec. 2004 & 57 & $25(50)$ & 900 & $1,138-2,193$ \\
\hline & Oct.-Dec. 2005 & 42 & $25(50)$ & 808 & $1,136-1,884$ \\
\hline \multirow[t]{3}{*}{ 2, Nam $\mathrm{Pa}$} & Oct.-Nov. 2003 & 39 & $24(48)$ & 667 & $826-1,521$ \\
\hline & Jan.-Feb. 2005 & 39 & $25(49)$ & 763 & $870-1,711$ \\
\hline & Dec. 2005-Jan. 2006 & 43 & $24(48)$ & 690 & $747-1,458$ \\
\hline \multirow[t]{3}{*}{ 3, Nam Ngao } & Dec. 2003-Jan. 2004 & 37 & $25(50)$ & 704 & $1,012-1,576$ \\
\hline & Mar.-Apr. 2005 & 49 & $25(50)$ & 958 & $1,057-1,629$ \\
\hline & Feb.-Apr. 2006 & 45 & $25(50)$ & 792 & $1,025-1,729$ \\
\hline 4, Phou Jae & Feb.-Mar. 2004 & 37 & $25(50)$ & 659 & $543-1,263$ \\
\hline 5, Thamla & Apr.-May 2004 & 37 & $25(50)$ & 730 & $1,194-1,706$ \\
\hline
\end{tabular}

PRESENCE 2.0 (Presence, 2009) to derive baseline occupancy estimates (the proportion of the area where the species was present) and detectability (P; the probability that a species was detected when present) following methods outlined by MacKenzie et al. (2006). Occupancy is used as a state variable for monitoring programmes to assess impact of management action (Manley et al., 2005) and is superior to count indices (individuals per unit effort) as a detection probability is incorporated into the occupancy estimate. We employed a single season, constant P model, treating each trap site as an individual sampling unit and grouped every 5 trap days at the site as a single sampling occasion, constructing a detection history consisting of a row of zeros (no photographs) and ones (photographs). Sites where both cameras operated for 10 days or less were removed from the analyses. We assumed a closed population within each block (the available literature for each species indicates that any deaths, births, immigration and emigration during the $30+$ day sampling period would be minimal) and that individuals did not travel between blocks (the available literature on each species indicates that individuals are not known to travel as far as the distances between our sampling blocks).

We used data from all surveys to determine the mean and range of altitudes of trap sites where each species was recorded. A binary logistic regression (using SPSS v. 16.0; SPSS, Chicago, USA) was used to determine if two predictors, the altitudes at which cameras were placed and camera-trap days at each altitude, had a significant influence on species detection. Two models were tested, one using altitude as a single predictor and another adding camera-trap days as an additional predictor. Goodness of fit of the two models was compared using the log likelihood of each model to determine if the additional predictor significantly improved the model.

We used data from all 11 surveys to determine activity patterns for each species. Each photo was identified to species and rated as a dependent or independent event following O'Brien et al. (2003). We examined the time stamped on the individual independent photographs and grouped activity times for each species into 3-hour time intervals (06.01-09.00, etc.) following Karanth \& Sunquist (2000). We used $\chi^{2}$ to determine if species were more likely to be diurnal (active from 06.01 to 18.00) or nocturnal (active from 18.01 to 06.00). Reproductive behaviour and independent photographs of groups of two or more individuals were noted.

\section{Results}

We deployed a total of 544 cameras for a total of 8,499 camera-trap days, at 273 trap sites, of which $93.9 \%$ had unexposed film remaining at the end of the sampling period. Only $2.9 \%$ of cameras finished a film or stopped recording during the first week and $1.8 \%$ during the following 2 weeks. The relatively low average misfire rate of only 3.0 cameras per sampling block $(n=11)$ was unlikely to affect analyses of survey results, given that cameras were paired.

Cameras recorded 472 photographs of 14 small carnivore species (Table 2), including six species that are globally threatened (IUCN, 2008; Schipper et al., 2008), one that is classified as At Risk in Laos and six as Little Known in Laos (Duckworth et al., 1999). Occupancy estimates were generated for seven species, ranging from $11 \% \pm$ SE 0.10 for marbled cat $(\mathrm{P}=0.205 \pm \mathrm{SE} 0.06)$ to $42 \% \pm \mathrm{SE} 0.14$ for Asian golden cat $(\mathrm{P}=0.050 \pm \mathrm{SE} 0.01)$. Rarely recorded species (stripe-backed weasel Mustela strigidorsa, small Indian civet Viverricula indica, spotted linsang Prionodon pardicolor, Owston's civet Chrotogale owstoni, crab-eating mongoose Herpestes urva and leopard cat Prionailurus bengalensis) had detection probabilities of $<0.02$ or standard errors in detection probability $>0.25$ such that occupancy could not be reliably estimated.

Small carnivores were recorded at $48 \%$ of sites and across the entire altitudinal range (Table 2). Three species 
TABLE 2 Records of the 14 species of small carnivores recorded in the five sampling blocks (Fig. 1, Table 1) during 2003-2006, with number of trap sites and percentage of total trap sites $(\mathrm{n}=273)$, number of independent photos, naïve occupancy, estimates of true occupancy (with SE) and detectability (P, with SE), altitude (mean and range) and status (globally and in Laos).

\begin{tabular}{|c|c|c|c|c|c|c|c|c|c|c|c|c|c|}
\hline \multirow[b]{2}{*}{ Common name, scientific name (by Family) } & \multicolumn{5}{|c|}{ Sampling block } & \multirow[b]{2}{*}{$\begin{array}{l}\text { Trap } \\
\text { sites }(\%)\end{array}$} & \multirow{2}{*}{$\begin{array}{l}\text { No. of } \\
\text { independent } \\
\text { photos }\end{array}$} & \multirow[b]{2}{*}{$\begin{array}{l}\text { Naïve } \\
\text { occupancy }^{1}\end{array}$} & \multirow[b]{2}{*}{$\begin{array}{l}\text { Occupancy } \\
(\mathrm{SE})^{2}\end{array}$} & \multirow[b]{2}{*}{$\mathrm{P}(\mathrm{SE})^{3}$} & \multirow[b]{2}{*}{$\begin{array}{l}\text { Mean altitude } \\
\text { (range; } \mathrm{m} \text { ) }\end{array}$} & \multicolumn{2}{|l|}{ Status $^{4}$} \\
\hline & 1 & 2 & 3 & 4 & 5 & & & & & & & Global & Laos \\
\hline \multicolumn{14}{|l|}{ Mustelidae } \\
\hline Striped-back weasel Mustela strigidorsa & + & & & & & $1(0.4)$ & 1 & & & & 1,687 & & LKL \\
\hline Yellow-throated marten Martes flavigula & + & + & + & + & + & $43(16)$ & 90 & 0.21 & $0.29(0.08)$ & $0.200(0.04)$ & $1,403(817-2,288)$ & & \\
\hline Hog badger Arctonyx collaris & + & + & + & & & $14(5)$ & 25 & 0.11 & $0.17(0.05)$ & $0.157(0.04)$ & $1,576(1,030-2,288)$ & NT & LKL \\
\hline $\begin{array}{l}\text { Oriental small-clawed otter Aonyx cinereus } \\
\text { Viverridae }\end{array}$ & & + & & & & $1(0.4)$ & 1 & & & & 971 & VU & ARL \\
\hline Large Indian civet Viverra zibetha & + & + & + & + & + & $25(9)$ & 34 & 0.14 & $0.36(0.15)$ & $0.078(0.04)$ & $1,252(905-1,687)$ & NT & \\
\hline Small Indian civet Viverricula indica & & & & + & & $2(1)$ & 3 & & & & $1,224(1,205-1,243)$ & & \\
\hline Spotted linsang ${ }^{5}$ Prionodon pardicolor & + & & + & + & & $6(2)$ & 7 & & & & $1,222(735-1,745)$ & & LKL \\
\hline Masked palm civet Paguma larvata & + & + & + & + & + & $23(8)$ & 39 & 0.12 & $0.14(0.04)$ & $0.237(0.05)$ & $1,437(735-2,288)$ & & \\
\hline $\begin{array}{l}\text { Common palm civet Paradoxurus } \\
\text { hermaphroditus }\end{array}$ & + & + & + & + & + & $18(7)$ & 31 & 0.11 & $0.16(0.14)$ & $0.175(0.05)$ & $1,228(735-1,743)$ & & \\
\hline $\begin{array}{l}\text { Owston's civet Chrotogale owstoni } \\
\text { Herpestidae }\end{array}$ & + & & & & & $1(0.4)$ & 1 & & & & 1,687 & VU & LKL \\
\hline $\begin{array}{l}\text { Crab-eating mongoose Herpestes urva } \\
\text { Felidae }\end{array}$ & + & + & + & + & + & $11(4)$ & 13 & & & & $1,151(639-1,486)$ & & \\
\hline Leopard cat Prionailurus bengalensis & + & + & + & + & + & $20(7)$ & 24 & & & & $1,398(543-2,288)$ & & \\
\hline Asian golden cat Pardofelis temminckii & + & + & + & + & & $37(14)$ & 48 & 0.12 & $0.42(0.14)$ & $0.050(0.01)$ & $1,357(849-2,228)$ & NT & LKL \\
\hline Marbled cat Pardofelis marmorata & + & & + & + & + & $24(9)$ & 39 & 0.08 & $0.11(0.10)$ & $0.205(0.06)$ & $1,485(1,043-1,913)$ & VU & LKL \\
\hline
\end{tabular}

${ }^{1}$ Naïve occupancy for the five sampling blocks for 2003-2004; does not incorporate detection probability (P)

${ }^{2}$ Estimate of true occupancy from the five sampling blocks for 2003-2004, incorporating detection probability (P)

${ }^{3}$ Detection probability in the five sampling blocks for 2003-2004

${ }^{4}$ VU, Vulnerable; NT, Near Threatened (IUCN, 2008; Schipper et al., 2008). ARL, At Risk in Laos; LKL, Little Known in Laos (Duckworth et al., 1999).

${ }^{5}$ Spotted linsang was recently reclassified, in the family Prionodontidae (Schipper et al., 2008) 
of mustelids were detected, over 817-2,288 m, with yellowthroated marten Martes flavigula, the most frequently detected small carnivore. The single stripe-backed weasel record was in montane evergreen habitat within $100 \mathrm{~m}$ of water, with 50\% crown cover and relatively open bamboo understorey. The single herpestid, the crab-eating mongoose, was recorded within an $847-\mathrm{m}$ band of mixed evergreen-deciduous forest habitat.

Six species of viverrids were recorded, over $735-2,288 \mathrm{~m}$, with masked palm civet Paguma larvata the most widely distributed. Large Indian civet Viverra zibetha was recorded at the highest proportion of sites but only over 905-1,687 m. All spotted linsang photographs $(n=7)$ were of individuals on the ground and in the open. Three of the six sites were near small streams and at two sites the species was on or near large tree buttresses. Small Indian civet occurred at sites with dense bamboo understorey in proximity to cultivated areas. Owston's civet was recorded at the same site where stripe-backed weasel was detected.

Three small felid species were recorded, over 543-2,228 m. Most (90\%) leopard cat detections were over 1,107-1,725 m. Marbled cat detections were restricted to an $870-\mathrm{m}$ strip above $1,000 \mathrm{~m}$.

Regression analysis (for those species detected at $>_{12}$ trap sites) indicated that altitudes where cameras were placed and camera-trap days were reliable predictors for presence of five species (Table 3). As altitude increased, odds of detection increased by $0.2 \%$ for marbled cat $(z=9.41, \mathrm{P}<0.01)$ and yellow-throated marten $(z=6.91$, $\mathrm{P}<0.01$ ). As camera-trap days increased, odds of Asian golden cat and large Indian civet being detected increased by $3.1 \%(z=10.63, \mathrm{P}=0.001)$ and $2.8 \%(z=7.60, \mathrm{P}<0.01)$, respectively. As altitude and camera-trap days increased,

TABLE 3 Logistic regression predicting presence of eight species (those detected at $>12$ trap sites) as a function of altitude where camera traps were placed (ALT) and camera-trap days at each altitude (CTD). Only the first model (with altitude) is reported unless adding camera-trap days significantly improved the model fit.

\begin{tabular}{llllll}
\hline & Variables & \multicolumn{2}{c}{ Wald test } & Odds \\
Species & in model & $B$ & $(z$ ratio $)$ & P & ratio \\
\hline $\begin{array}{l}\text { Yellow-throated } \\
\quad \text { marten }\end{array}$ & ALT & 0.002 & 6.91 & $<0.01$ & 1.002 \\
Hog badger & & & & & \\
& ALT & 0.004 & 12.63 & $<0.001$ & 1.004 \\
Large Indian civet & CTD & 0.047 & 11.72 & 0.001 & 1.048 \\
& ALT & 0.000 & 1.08 & 0.299 & 0.999 \\
Masked palm civet & CTD & 0.028 & 7.60 & $<0.01$ & 1.028 \\
Common palm civet & ALT & 0.001 & 1.93 & 0.165 & 1.001 \\
Leopard cat & ALT & 0.000 & 0.19 & 0.661 & 1.000 \\
Asian golden cat & ALT & 0.000 & 0.24 & 0.626 & 1.000 \\
& CTD & 0.031 & 10.63 & 0.147 & 1.001 \\
Marbled cat & ALT & 0.002 & 9.41 & $<0.01$ & 1.0031 \\
\hline
\end{tabular}

odds of detecting hog badger Arctonyx collaris increased by $0.4 \%(z=12.63, \mathrm{P}<0.001)$ and $4.8 \%(z=11.72, \mathrm{P}=0.001)$, respectively.

We identified a total of 356 independent photographs of the 14 small carnivore species (Table 2). Of these, 328 had date stamps that could be used to determine activity patterns. Mustelids were photographed at all time intervals $(n=107)$. Hog badger was not any more likely to be detected during the day than at night $(\varphi=1.087, \mathrm{n}=23$, $\mathrm{P}=0.297$ ), while yellow-throated marten was more likely to be recorded during the day $(\varphi=25.805, \mathrm{n}=82$, $\mathrm{P}<0.001)$. The single stripe-backed weasel was recorded at 08.57, April 2003. Detections of crab-eating mongoose were only during daylight with $60 \%(\mathrm{n}=10)$ from 06.00 to 09.00 .

Most viverrids were recorded at night $(97 \% ; \mathrm{n}=107)$ except for $3 \%(\mathrm{n}=36)$ of masked palm civet detections during daylight. Of the uncommon viverrids, small Indian civet was recorded at 19.59 and 20.30 (March 2004) and 22.14 (February 2004). Owston's civet was detected only at 23.45, April 2003. Spotted linsang was recorded at 20.33 (January 2004), 00.46 (April 2003), 02.03 (November 2004) and 03.25 (February 2004).

Small felids were recorded at all time intervals $(n=104)$. Asian golden cat was not any more likely to be detected at night than during the day ( $\mathrm{phi}=1.14, \mathrm{n}=43, \mathrm{P}=0.286$ ). Leopard cat was more likely to be recorded at night ( $\mathrm{phi}=13.50, \mathrm{n}=24, \mathrm{P}<0.001$ ), and marbled cat was more likely to be recorded during daylight $(\mathrm{phi}=7.81, \mathrm{n}=37$, $\mathrm{P}<0.005)$.

Only $6 \%$ of independent photographs depicted more than one individual: pairs of yellow-throated marten $(\mathrm{n}=9)$, masked palm civet $(\mathrm{n}=3)$, Asian golden cat $(n=2)$, marbled cat $(n=1)$ and leopard cat $(n=1)$ and groups of 2-3 crab-eating mongooses $(n=4)$.

\section{Discussion}

This survey confirms that Nam Et-Phou Louey National Protected Area harbours at least six small carnivore species of global conservation concern and is one of the most important areas for diversity of small carnivores in Laos. This has important implications for management.

Occupancy estimates for the most frequently occurring species are statistically robust and useful as a population index over time, although results should be interpreted cautiously. Detections overall are low, which may be partly because of previously unmanaged hunting (Davidson, 1998; Vongkhamheng, 2002; Johnson et al., 2006), something common in Laos (Duckworth et al., 1999; Nooreen \& Claridge, 2001). Coefficients of variation indicate moderate to high sampling variability (29-90\%) such that occupancy estimates may be positively biased upwards by $10-15 \%$ of their true value. Detections by camera trapping are 
probably low for five of the most common species that spend some part of their time above the forest floor. Palm civets occur from the forest floor to the canopy, yellowthroated marten and the Asian golden cat occasionally climb and marbled cat morphology is believed to support arboreality (Duckworth, 1997; Sunquist \& Sunquist, 2002). Home ranges are unknown for the area, and for some species may exceed the subunit area sampled such that occupancy estimates represent an area that is used by the species rather than the extent of its occcurence (MacKenzie et al., 2006). For example, estimated home ranges for Asian golden cat from telemetry studies in Thailand are 32.6-82.5 $\mathrm{km}^{2}$ (Grassman et al., 2005b). For other species occupancy probably approximates presence where estimated home ranges from telemetry studies in comparable habitats are similar to the subunit area: common palm civet $(1.1-4.25$ $\left.\mathrm{km}^{2}\right)$, masked palm civet $\left(3.7-5.9 \mathrm{~km}^{2}\right)$, marbled cat $(5.3-5.8$ $\left.\mathrm{km}^{2}\right)$ and yellow-throated marten (0.7-10.5 km² witz, 1991; Grassman, 1998; Grassman et al., 2005a).

Of the globally threatened species recorded during our surveys, the Near Threatened Asian golden cat was the second most frequently detected small carnivore in Nam Et-Phou Louey National Protected Area, compared to being reportedly rare in most areas surveyed from Tibet to Sumatra (Sunquist \& Sunquist, 2002). In Laos it was believed to be one of the more numerous small felids (Duckworth et al., 1999), although surveys in central Laos since 2006 detected it only once in 7,690 camera-trap days in $400 \mathrm{~km}^{2}$ of evergreen forest in Nakai-Nam Theun National Protected Area (Johnson \& Johnston, 2007) and at $7 \%$ of sites $(n=95)$ during 3,053 camera-trap days in $200 \mathrm{~km}^{2}$ of dry evergreen forest in Nam Kading National Protected Area (WCS-Laos, unpubl. data), which possibly illustrates the impact that overhunting has had in these areas. Another positive indicator of the status of Asian golden cat in Nam Et-Phou Louey National Protected Area was evidence of a rarely recorded reproductive behaviour, depicted in a series of 29 consecutive photographs, resembling that described from the species in captivity (Mellen, 1993).

It is unclear if the lack of records of the Vulnerable marbled cat elsewhere in Asia is because of rarity or reclusiveness (Sunquist \& Sunquist, 2002) but in Laos it is also little known (Duckworth et al., 1999). Camera-trap surveys since 2006 failed to detect it in Nakai-Nam Theun National Protected Area and it was recorded at only $4 \%$ of trap sites $(n=95)$ in Nam Kading National Protected Area (WCS-Laos, unpubl. data). Our study and previous surveys in Laos (Duckworth et al., 1999) suggest a potential affinity for montane evergreen forest above $1,000 \mathrm{~m}$. Contrary to reports that it is nocturnal (Sunquist \& Sunquist, 2002), we found it to be primarily diurnal.

The Vulnerable Owston's civet, known only from Vietnam, China and Laos (Schreiber et al., 1989; Dang et al., 1992; Rozhnov et al., 1992) is the first record in the wild from Laos. This record in Nam Et-Phou Louey falls between locations where the species is known to occur in Sonla Province, Vietnam, and in the Nakai-Nam Theun National Protected Area in central Laos, where it was photographed in the wild in 2006 (Johnson \& Johnston, 2007). Its detection on the north-east of Phou Louey mountain, along with stripe-backed weasel, further indicates the potential importance of the Nam Et-Phou Louey's montane evergreen forest habitat.

The global status of the striped-back weasel was recently reduced from Vulnerable to Least Concern (Schipper et al., 2008) as it is now known from several locations in Asia (Abramov et al., 2008). Although no longer thought to require urgent conservation attention, extensive sampling in seemingly suitable habitat in Nam Et-Phou Louey National Protected Area suggests that it may not be common or, at least, not easily detected.

Two other species Little Known in Laos are spotted linsang and the Near Threatened hog badger. The paucity of records of spotted linsang in the Protected Area concurs with it being rarely recorded elsewhere across its range despite being known from forests over a wide altitudinal gradient (Van Rompaey, 1995; Duckworth, 1997). Although hog badger is hunted for medicinal use and subsistence consumption in the Protected Area, the species is still detected above $1,000 \mathrm{~m}$, being as frequently detected at night as during the day, contrary to reports of it being mainly diurnal (Duckworth, 1997).

Comparing our findings to recent camera trap surveys in central Laos, two species expected but not detected were ferret badger Melogale sp. and binturong Arctictis binturong. Although both were reported in interviews with villagers living near the Protected Area (Davidson, 1998), ferret badger was not confirmed until photographed in a village in 2008. The absence of detections of binturong may indicate that it has been reduced to very low numbers or that it was never present.

Applying our findings to management, in early 2008 Nam Et-Phou Louey National Protected Area established a contiguous $3,000-\mathrm{km}^{2}$ core zone, including the montane evergreen forest areas identified as important in this study, where habitat conversion and hunting are prohibited (GoL, 2008). The regulations also specify that most globally threatened or rarely detected small carnivores recorded in our study cannot be harvested (stripe-backed weasel, all otter species, Owston's civet, spotted linsang, binturong, leopard cat, Asian golden cat and marbled cat). Given that hunting is still important for the subsistence of ethnic minorities in the uplands of Laos (Krahn \& Johnson, 2007), the regulations specify that the more common small carnivores can be harvested by villagers outside the core zone but offtake is limited by season and gear, with trade prohibited. One exception that requires immediate attention is the large Indian civet, which was recently elevated to 
Near Threatened status but is still listed as a species for year-round harvest in Laos. The Protected Area, with support from the Wildlife Conservation Society, continues to monitor carnivore populations systematically to determine if guidelines are meeting their stated objectives. To understand small carnivore diversity and status more fully, future monitoring should consider additional methods to assess species that are primarily arboreal (e.g. palm civets), that exhibit seasonality (e.g. hog badger), are largely aquatic (e.g. otters), are uncommon ground dwellers, such as weasels, that may not frequent clearings, and those that show preferences for disturbed areas, such as small Indian civet.

\section{Acknowledgements}

This study was conducted under the Endangered Species Memorandum of Understanding between the Department of Forestry and the Wildlife Conservation Society. We thank William Duckworth for extensive comments on earlier drafts, Timothy O'Brien for guidance on study design, and Samantha Strindberg, Michael Hedemark, Anthony Lynam and Scott Roberton for additional advice and assistance. We are grateful to Bouathong Xayavong and Nam Et-Phou Louey National Protected Area survey team members and to Vene Vongphet and government authorities in Houaphan and Luang Prabang provinces for administrative support.

\section{References}

Abramov, A.V., Duckworth, J.W., Wang, Y.-X. \& Roberton, S.I. (2008) The stripe-backed weasel Mustela strigidorsa: taxonomy, ecology, distribution and status. Mammal Review, 38, $247-266$.

Dang, N.X., Anh, P.T. \& Huynh, D.H. (1992) The biology and status of Owston's palm civet in Vietnam. Small Carnivore Conservation, 6, 5-7.

Davidson, P. (1998) A Wildife and Habitat Survey of Nam Et Phou Louey National Biodiversity Conservation Areas, Houaphanh Province. Wildlife Conservation Society, Vientiane, Lao PDR.

DUCKWorth, J.W. (1997) Small carnivores in Laos: a status review with notes on ecology, behaviour and conservation. Small Carnivore Conservation, 16, 1-21.

Duckworth, J.W., Salter, R.E. \& Khounboline, K. (1999) Wildlife in Lao PDR: 1999 Status Report. IUCN, Vientiane, Lao PDR.

GoL (Government of LaO PDR) (2005) Forestry Strategy to the Year 2020 of the Lao PDR. Office of the Prime Minister, Vientiane, Lao PDR.

GoL (Government of Lao PDR) (2007) Wildlife Law 07. 24 December 2007. National Assembly, Vientiane, Lao PDR.

GoL (Government of Lao PDR) (2008) Regulation on Protected Area and Wildlife Management in the Nam Et-Phou Louey National Protected Area. Office of District Governor, Viengthong District, Houaphan Province, Lao PDR.
Grassman, L.I. (1998) Movement and fruit selection of two Paradoxurinae species in a dry evergreen forest in southern Thailand. Small Carnivore Conservation, 19, 25-29.

Grassman, L.I.J., Tewes, M.E. \& Silvy, N.J. (2005a) Ranging, habitat use and activity patterns of binturong Arctictis binturong and yellow-throated marten Martes flavigula in north-central Thailand. Wildlife Biology, 11, 49-57.

Grassman, L.I.J., Tewes, M.E., Silvy, N.J. \& Kreetiyutanont, K. (2005b) Ecology of three sympatric felids in a mixed evergreen forest in north-central Thailand. Journal of Mammology, 86, 29-38.

ICEM (2003) Review of Protected Areas and Development in the Lower Mekong River Region. International Centre for Environmental Management, Indooroopilly, Australia.

IUCN (2008) 2008 IUCN Red List of Threatened Species. IUCN, Gland, Switzerland. Http://www.iucnredlist.org/ [accessed 13 August 2008].

Johnson, A. \& Johnston, J. (2007) Biodiversity Monitoring and Enforcement Project in the Nam Theun 2 Watershed. Final Report V1.1. Wildlife Conservation Society, Vientiane, Lao PDR.

Johnson, A., Singh, S. \& Duongdala, M. (2005) Wildlife hunting and use in Luang Namtha Province: implications for rural livelihoods and biodiversity conservation in the uplands of the Lao PDR. In Poverty Reduction and Shifting Cultivation Stabilisation in the Uplands of Lao PDR: Technologies, Approaches and Methods for Improving Upland Livelihoods (eds B. Bouahom, A. Glendinning, S. Nilsson \& M. Victor), pp. 195-208. National Agriculture and Forestry Research Institute, Luang Prabang, Lao PDR.

Johnson, A., Vongkhamheng, C., Hedemark, M. \& SAithongDam, T. (2006) Effects of human-carnivore conflict on tiger (Panthera tigris) and prey populations in Lao PDR. Animal Conservation, 9, 421-430.

KARANTH, K.U. \& SUnqUist, M.E. (2000) Behavioural correlates of predation by tiger (Panthera tigris), leopard (Panthera pardus) and dhole (Cuon alpinus) in Nagarahole, India. Journal of Zoology (London), 250, 255-265.

Krahn, J. \& Johnson, A. (2007) Food security and wildlife management. Juth Pakai, 9, 17-33.

MacKenzie, D.I., Nichols, J.D., Royle, J.A., Pollock, K.H., BAiley, L.L. \& Hines, J.E. (2006) Occupancy Estimation and Modeling: Inferring Patterns and Dynamics of Species Occurrence. Academic Press, London, UK.

Manley, P.N., Schlesinger, M.D., Roth, J.K. \& Van Horne, B. (2005) A field-based evaluation of a presence-absence protocol for monitoring ecoregional-scale biodiversity. Journal of Wildlife Management, 69, 950-966.

Mellen, J.D. (1993) A comparative analysis of scent-marking, social and reproductive behavior in 20 species of small cats (Felis). American Zoologist, 33, 151-166.

Nooren, H. \& Claridge, G. (2001) Wildlife Trade in Laos: The End of the Game. Netherlands Committee for IUCN, Amsterdam, The Netherlands.

O'Brien, T.G., Kinnaird, M.F. \& Wibisono, H.T. (2003) Crouching tigers, hidden prey: Sumatran tiger and prey populations in a tropical forest landscape. Animal Conservation, 6, 131-139.

PRESENCE (2009) Http://www.mbr-pwrc.usgs.gov/software [accessed 11 August 2009].

Rabinowitz, A.R. (1991) Behaviour and movements of sympatric civet species in Huai Kha Khaeng Wildlife Sanctuary, Thailand. Journal of Zoology (London), 221, 281-298.

Rozhnov, V.V., Kuznetzov, G.V. \& Anh, P.T. (1992) New distributional information on Owston's palm civet. Small Carnivore Conservation, 6, 7 . 
Schipper, J., Hoffman, M., Duckworth, J.W. \& Conroy, J. (2008) The 2008 IUCN red listings of the world's smallest carnivores. Small Carnivore Conservation, 39, 29-34.

Schreiber, A., Wirth, R., Riffel, M. \& Rompaey, H.V. (1989) Weasels, Civets, Mongooses and Their Relatives. An Action Plan for the Conservation of Mustelids and Viverrids. IUCN, Gland, Switzerland.

Sunquist, M. \& Sunquist, F. (2002) Wild Cats of the World. University of Chicago Press, Chicago, USA.

Van Rompaey, H. (1995) The spotted linsang Prionodon pardicolor. Small Carnivore Conservation, 13, 10-12.

Vongkhamheng, C. (2002) Participatory Wildlife Diversity Monitoring with Different Ethnic Groups in Nam Et-Phou Louey National Biodiversity Conservation Areas, Northern Lao PDR. MSc thesis, Mahidol University, Bangkok, Thailand.
Webi, L.J., Tracey, J.G. \& Williams, W.T. (1976) The value of structural features in tropical forest typology. Australian Journal of Ecology, 1, 3-28.

\section{Biographical sketches}

Arlyne Johnson is the co-director of the Wildlife Conservation Society-Lao PDR Program and coordinates monitoring projects that measure the effects of protected area management on the conservation of large mammals and birds. Chanthavy VongKhamheng is a wildlife biologist studying the abundance and distribution of tigers and their prey in Laos. ThAvisouk SAITHONGDAM is a wildlife biologist working on the long-term monitoring of large mammals in the Nam Et-Phou Louey National Protected Area. 